\title{
KADAR FORMALIN PADA IKAN ASIN JAMBAL ROTI (Arius thalassinus) DI KAWASAN WISATA TELUK PENYU CILACAP TAHUN 2014
}

\author{
Seti Yuliowati ${ }^{*}$ ), Febri Apwanti, SKM ${ }^{* *}$ )
}

Abstract

Background and objectives, Fish was an export commodity that decays faster than fruits and vegetables. Jambal roti fish is salted fish products derived from Manyung fish (Arius thalassinus), is one of the food ingredients commonly mixed with food additive that forbidden by the government, namely formalin. The purpose of the study was to determine the formaldehyde levels content in jambal roti (Arius thalassinus) salted fish sold in Teluk Penyu tourist resort Cilacap 2014.

The research design used was descriptive research with lab analyst, to obtain vivid description related Jambal roti salted fish (Arius thalassinus)physical condition, measuring the traders knowledge level and formaldehyde levels examination jambal roti (Arius thalassinus) salted fish sold in Teluk Penyu tourist resort Cilacap 2014.

The research results shows from 10 samples the Jambal roti salted fish (Arius thalassinus) physical condition measured with organoleptic obtained good categories with $70 \%$ percentage. The examination results shows that from 10 samples, 9 samples proved negative (did not contain formaldehyde) on the number of samples $1,2,3,4,5,7,8,9,10$ and 1 sample contained $0.5 \mathrm{mg}$ of formaldehyde which is sample number 6.

The conclusions drawn was the tested samples number 6 positive containing formaldehyde $0.5 \mathrm{mg}$, so that sample number 6 declared not safe for public consumption. The trader knowledge level related forbidden food additive was poor, researchers need to provide discourse related formaldehyde danger if used as food additive in the future so that the trader knows about the dangers of formaldehyde was a forbidden food additive.

$\begin{array}{ll}\text { References } & : 19(1987-2013) \\ \text { Keywords } & : \text { Physical Condition, Formaldehyde Knowledge Level } \\ \text { Classification } & : \text { Vector Control }\end{array}$

*) Alumni Mahasiswa Jurusan Kesehatan Lingkungan Purwokerto

${ }^{* *}$ ) Dosen Jurusan Kesehatan Lingkungan Purwokerto

\section{PENDAHULUAN}

\section{A. Latar Belakang Masalah}

Inspeksi yang dilakukan oleh Dinas Kelautan, Perikanan, dan Peternakan menemukan produk makanan mengandung formalin ditiga pasar tradisional daerah Kulonporogo yaitu ikan asin kering dan cumicumi. Saat diteliti, terlihat warna ungu pekat yang menandakan kadar formalin yang sangat tinggi dan melebihi batas yang diperbolehkan. Fakta di atas sangat bertentangan dengan PERMENKES RI No.033/MENKES/PER/IX/2012 yang menyatakan bahwa formalin termasuk salah satu bahan tambahan yang dilarang dipergunakan dalam makanan karena bersifat karsinogenik dan membahayakan kesehatan (liputan6, 2011).

Ikan asin merupakan salah satu produk pangan yang sangat popular di Indonesia dan digemari oleh masyarakat ekonomi kelas atas maupun bawah. Pemeintah Indonesia juga menetapkan Ikan asin sebagai salah satu dari 9 (Sembilan) kebutuhan pokok masyarakat karena termasuk unsur penting dalam peningkatan gizi yang harganya relative terjangkau. Selain harganya terjangkau pengawetan Ikan menjadi Ikan asin merupakan cara yang paling mudah dalam menyelamatkan hasil tangkapan oleh nelayan. Proses produksi ikan asin awalnya hanya melalui penggaraman dan pengeringan namun untuk mendapatkan keuntungan yang lebih besar saat ini para produsen Ikan asin menggunakan formalin sebagai bahan pengawet dalam proses produksi (Rachmawati, 2006).

Banyak bahan kimia yang digunakan dalam pencampuran pembuatan/pengolahan makanan dengan tujuan memperbaiki tekstur dan memiliki masa simpan yang lebih lama dibandingkan makanan yang tidak berpengawet. Salah satu contoh bahan kimia berbahaya adalah "Formalin". Formalin itu sendiri sebenarnya sangat berbahaya dan merugikan bagi kesehatan organ tubuh manusia hal ini sangat penting, permasalahan ini merupakan salah satu yang harus diperbaiki. Jika kita mengabaikan masalah ini maka yang akan terjadi adalah bertambah luasnya penyalah gunaan 
formalin pada bahan makanan sebagai bahan pengawetnya. Dimana masyarakat pada umumnya akan memperoleh dampak negatifnya apabila kegiatan yang seperti ini dibiarkan terus-menerus (Cahyadi, 2006).

Formalin sebenarnya sudah sangat umum digunakan dalam kehidupan sehari-hari. Disektor industri formalin/Formaldehid mempunyai banyak manfaat yaitu untuk pembersih lantai, kapal, gudang-gudang, pakaian, pembasmi lalat dan berbagai serangga. Namun demikian mengenai masalah formalin, perhatian pemerintah kita masih kurang perhatian, karena selain digunakan dalam sektor industri, formalin juga disalah gunakan untuk keperluan lain seperti pengawetan makanan yang sangat tidak baik apabila di konsumsi oleh tubuh manusia. Formalin sangat berbahaya jika dihirup, mengenai kulit dan tertelan. Jika dikonsumsi dalam jangka panjang maka formaldehid dapat merusak hati, ginjal, limpa, pankreas, dan gangguan kesehatan lainnya. Penyebab masih tingginya prevalensi masalah formalin adalah kurangnya informasi dan pengetahuan masyarakat terhadap formalin. Kandungan formalin dirasa lebih mudah dan murah sebagai bahan pengawet makanan dalam pangan.

Maraknya penggunaan formalin oleh para nelayan membuktikan lemahnya regulasi dan pengawasan terhadap penggunaan bahan kimia berbahaya tersebut,padahal kebijakan yang mengatur penggunaan formalin telah dikeluarkan oleh pemerintah. Pemerintah telah mengeluarkan peraturan untuk formalin, yaitu Permenkes RI No.033/MENKES/X/2012 tentang Bahan Tambahan Pangan, Peraturan Pemerintah No.28 tahun 2004 tentang Keamanan Mutu dan Gizi Pangan. Undang-undang (UU) No.7 tahun 1996 tentang pangan, Peraturan Mentri Kesehatan RI No.472 tahun 1996 tentang Pengamanan Bahan Berbahaya Bagi Kesehatan, Peraturan Menteri Kesehatan No.722 tahun 1988 yang diperkuat dengan Peraturan Mentri Kesehatan No.1168 tahun 1999 Tentang Bahan Tambahan Makanan, Keputusan Mentri Perindustrian Dan Perdagangan No.254 tahun 2000 Tentang Tata Niaga Impor dan Peredaran Bahan Berbahaya Tertentu serta

Undang-undang (UU) No.8 tahun 1999 tentang perlindungan konsumen yang memberikan ancaman berat bagi penyalahgunaan formalin. Berdasarkan peraturan-peraturan tersebut, formalin termasuk dalam kategori bahan berbahaya yang penggunaannya harus diawasi, namun peraturan tersebut selama ini seolah-olah tidak berlaku sebagai mana mestinya dalam menghentikan penggunaan formalin dalam produk pangan seperti ikan asin (Hustyani dan Siti, 2006).

Pemkab Malang melalui Dinas Kelautan dan Perikanan (DKP) Kab Malang merilis hasil investigasi dan pengujian Lab yang dilakukan balai besar pengawasan obat dan makanan (BB POM) di Jakarta menemukan sejumlah produk pangan yang berasal dari perikanan memakai formalin sebagai bahan pengawet. Karenanya Dinas Kelautan Dan Perikanan mengajak masyarakatnya untuk lebih ekstra waspada terhadap jenis ikan asin diantaranya ikan asin sotong, ikan asin sange belah, ikan cucut daging super ikan sepat kering, ikan tipis tawar kering, ikan teri, ikan cumi kering, cumi tawar dan ikan asin jambal roti. Dalam penanganan ikan yang paling penting harus diperhatikan adalah mutu ikan dari segi keamanan atau tidak menggunakan bahan kimia, kebersihan dan kelayakan untuk dikonsumsi. Terang Kepala Dinas Kelautan Dan Perikanan Kab.Malang Wahyu Hidayat kepada Malang post (Malangpost, 2014).

Berdasarkan survay penelitian yang dilakukan oleh Chanif Mahdi dan Shofy Mubarrak, Malang (2008) dari 10 sampel produk ikan asin kering dari tempat yang berbeda lebih dari $60 \%$ positif mengandung formalin (Mahdi C, 2008).

Ikan jambal roti adalah produk ikan asin yang berasal dari ikan Manyung (Arius thalassinus). Istilah jambal roti digunakan karena karakter tekstur dagingnya yang mudah hancur setelah digoreng seperti roti panggang dengan aroma yang khas (Burhannudin, 1987).

Peneliti memilih ikan asin jenis Jambal roti (Arius thalassinus) karena menemukan beberapa indikasi yang dimungkinkan sebagai tanda keberadaan formalin pada ikan asin Jambal roti di kawasan wisata Teluk Penyu Cilacap, Indikasi yang muncul antara lain ikan asin teksturnya lebih keras pada saat peneliti melakukan penekanan, ikan asin tidak di hinggapi oleh lalat, melihat persoalan tersebut, maka saya akan mengadakan penelitian untuk mengetahui kadar formalin pada ikan asin Jambal roti (Arius thalassinus) yang dijual di kawasan wisata Teluk Penyu Cilacap Tahun 2014.

Teluk penyu merupakan kawasan pantai di Selatan Kabupaten Cilacap utamanya sepanjang pesisir dari Kecamatan Cilacap Selatan yang lokasinya tidak langsung berhubungan dengan Samudra India atau Indonesia karena dikelilingi oleh pulau Nusakambangan. Pantai teluk penyu berjarak $2 \mathrm{Km}$ kearah timur dari pusat pemerintahan Kabupaten Cilacap dan dapat dijangkau dengan kendaraan umum dan pribadi. Teluk ini cukup memiliki 
pemandangan yang indah dengan luas kirakira $14 \mathrm{Ha}$. Area teluk penyu yang biasa dikunjungi oleh para pengunjung (utamanya penduduk dan wisatawan lokal) biasanya mulai dari pelabuhan perikanan samudra dari hingga bibir pantai. Dari arah pintu masuk area wisata Pantai Teluk Penyu banyak berdiri kios-kios yang menjajakan ikan asin kering ada 40 penjual ikan asin yang dijual disepanjang koridor jalan masuk lokasi wisata ini. Kawasan wisata ini ramai dikunjungi pada waktu pagi dan sore hari oleh para penduduk kota Cilacap sedangkan pada siang hari lebih banyak dikunjungi oleh para wisatawan lokal utamanya pada masamasa libur sekolah atau pada hari-hari besar.

Berdasarkan

latar belakang/permasalahan diatas penulis berkeinginan mengadakan penelitian dengan judul "Kadar Formalin pada Ikan Asin Jambal Roti (Arius thalassinus) di Kawasan Wisata Teluk Penyu Cilacap Tahun 2014".

\section{B. Perumusan Masalah}

Apakah terdapat kadar formalin pada ikan asin Jambal roti (Arius thalassinus) yang dijual di kawasan Wisata Teluk Penyu Cilacap Tahun 2014?

\section{Tujuan Penulisan}

1. Tujuan Umum

Mengukur kadar formalin yang terdapat pada ikan asin Jambal roti (Arius thalassinus) yang dijual oleh pedagang di kawasan Wisata Teluk Penyu Cilacap Tahun 2014 ?

2. Tujuan Khusus

a. Mengukur kondisi fisik ikan asin Jambal roti (Arius thalassinus).

b. Mengukur tingkat pengetahuan pedangan tentang formalin pada ikan asin Jambal roti (Arius thalassinus).

c. Mengukur keberadaan kadar formalin pada ikan asin Jambal roti (Arius thalassinus).

d. Mengukur besarnya kadar (mg) formalin dalam ikan asin Jambal roti (Arius thalassinus).

e. Mengetahui ciri-ciri fisik ikan asin Jambal roti (Arius thalassinus) yang mengandung formalin dan tanpa formalin.

\section{Manfaat Penelitian}

\section{Bagi Masyarakat}

Hasil penelitian ini diharapkan dapat memberikan informasi kepada masyarakat mengenai keberadaan formailin dan besarnya kadar formalin dalam ikan asin Jambal roti yang dijual di kawasan wisata Teluk Penyu Cilacap Tahun 2014.
2. Bagi Institusi Pendidikan

Sebagai tambahan informasi dan kepustakaan serta pengembangan ilmu pengetahuan.

3. Bagi Peneliti

Diperoleh tambahan pengetahuan, pengalaman, dan penerapan teori yang telah diperoleh selama perkuliahan dalam melakukan penelitian kadar formalin pada ikan asin.

4. Bagi Tenaga Kesehatan

Sebagai bahan masukan bagi sanitarian untuk meningkatkan kualitas pelayanan penanganan kandungan bahan kimia (formalin) pada ikan asin bagi pedagang.

\section{METODE PENELITIAN}

\section{A. Kerangka Pikir}

1. Komponen Penyusunan

a. Input
1) Penjamah
2) Tempat
3) Alat dan bahan
4) Metode Penelitian

b. Proses

Langkah-langkah pengambilan sampel kadar formalin pada ikan asin Jambal roti (Arius thalassinus) terdiri dari:

1) Mempersiapkan Alat dan Bahan yang akan digunakan untuk pengambilan sampel ikan asin Jambal roti (Arius thalassinus) yang dijual di kawasan wisata Teluk Penyu Cilacap.

2) Melakukan pengambilan sampel ikan asin Jambal roti (Arius thalassinus) yang dijual di Kawasan wisata Teluk Penyu Cilacap dengan prosedur pengambilan sampel yang benar.

c. Output Kualitas pada ikan asin Jambal roti (Arius thalassinus) yang diuji keberadaan kadar formalin. 
2. Kerangka Pikir

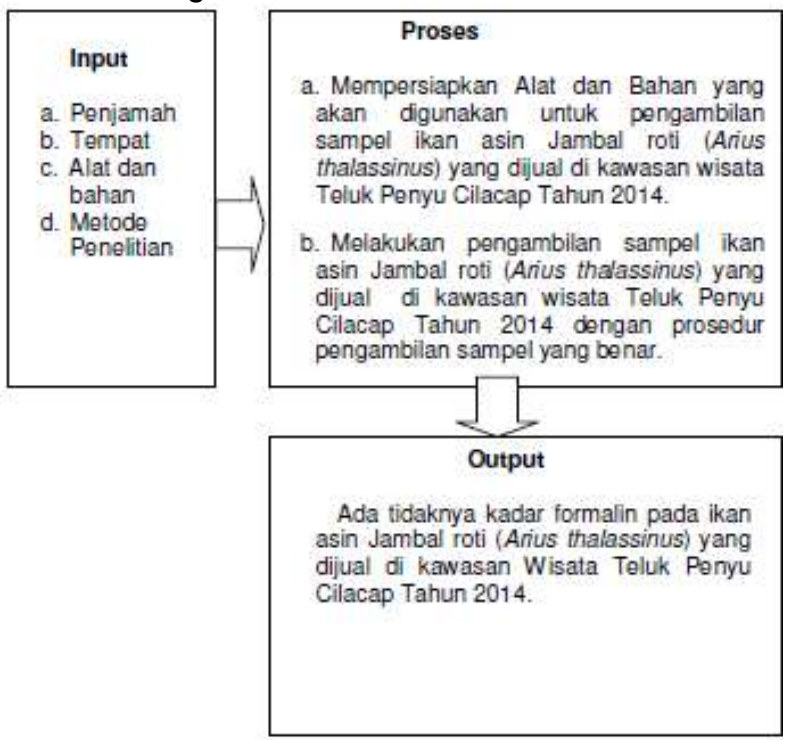

Gambar 2.1 Kerangka Pikir

\section{B. Jenis Penelitian}

Penelitian ini termasuk penelitian deskriptif dengan analis laboratorium, untuk memperoleh gambaran tentang hasil pemeriksaan kadar formalin pada ikan asin Jambal roti (Arius thalassinus) di kawasan wisata Teluk Penyu Cilacap Tahun 2014. Penelitian ini dilakukan dengan pengumpulan data lapangan dan pemeriksaan secara laboratorium yang kemudian hasilnya dibandingkan dengan ketentuan perundangundangan atau standar yang berlaku.

\section{Ruang Lingkup}

1. Waktu

a. Tahap persiapan : November 2013 Februari 2014

b. Tahap pelaksanaan : Maret 2014 Juni 2014

c. Tahap penyelesaian : Juni 2014

2. Lokasi

Lokasi penelitian ini dilakukan di kawasan wisata Teluk Penyu Cilacap.

3. Materi

Penelitian ini menjelaskan tentang kadar formalin yang terdapat pada ikan asin Jambal roti (Arius thalassinus).

\section{Subyek Penelitian}

Subjek penelitiannya adalah kadar Formalin yang terdapat pada ikan asin Jambal roti (Arius thalassinus) di kawasan wisata Teluk Penyu Cilacap sebanyak 10 sampel.

\section{E. Pengumpulan Data}

1. Jenis Data

a. Data Umum
Data umum dalam penelitian ini mengenai lokasi penjualan ikan asin Jambal roti di kawasan wisata Teluk Penyu Cilacap Tahun 2014. Banyaknya ikan yang dijual, prosedur penjualan, tingkat kepemahaman penjual tentang formalin.

b. Data Khusus

Data khusus dalam penelitian ini mengenai kadar formalin pada ikan asin Jambal roti di kawasan wisata Teluk Penyu Cilacap Tahun 2014.

2. Sumber Data

\section{a. Data Primer}

Data primer dalam penelitian ini diperoleh dari beberapa metode penelitian yaitu menggunakan observasi/pengamatan secara langsung, pengambilan data dan informasi, serta wawancara.

b. Data Sekunder

Data sekunder dalam penelitian ini diperoleh dari daftar pustaka (yang dijadikan landasan teori), informasi dari penjual ikan asin, serta hasil pengujian kadar formalin di Laboratorium Kampus 7 Poltekkes Kemenkes Semarang.

3. Cara Pengumpulan Data

a. Observasi : Penulis melakukan pengumpulan data dengan cara melihat langsung objek yang akan diteliti yaitu ikan asin Jambal roti di kawasan wisata Teluk Penyu Cilacap Tahun 2014.

b. Wawancara : Penulis mengumpulkan data dengan cara mengajukan beberapa pertanyaan kepada pedagang ikan asin Jambal roti di kawasan wisata Teluk Penyu Cilacap Tahun 2014.

c. Pemeriksaan Laboratorium : Penulis melakukan pemeriksaan uji kadar formalin terhadap sampel ikan asin Jambal roti di laboratorium.

4. Instrumen Penilitian

a. Checklist : yaitu daftar penyataan yang ditujukan untuk mengobservasi tempat penelitian.

b. Kuesioner : yaitu alat yang digunakan untuk mengumpulkan data dengan cara bertanya atau menanyai responden sesuai dengan data yang ingin dikumpulkan ditujukan kepada responden.

c. Uji Laboratorium (Rapid test kit).

\section{F. Analisis Data}

Analisis data dalam penelitian ini menganalis secara deskriptif terhadap datadata yang tertera pada tabel hasil. 


\section{HASIL}

\section{A. Gambaran Umum}

1. Sejarah Singkat Pantai Teluk Penyu Cilacap

Obyek Wisata Pantai Teluk Penyu Cilacap adalah obyek wisata pantai selatan atau Samudra Hindia terletak di wilayah Kelurahan Cilacap, Kecamatan Cilacap Selatan Kabupaten Cilacap, 1 km dari kantor kelurahan dan $2 \mathrm{~km}$ dari pusat pemerintahan Kabupaten Cilacap dapat ditempuh dengan kendaraan pribadi dan kendaraan umum angkutan wisata.

Kondisi Pantai Teluk Penyu yang landau dengan deburan ombak yang relative besar memberikan pemandangan tersendiri disamping panorama pulau Nusakambangan dan perahu nelayan ditengah lautan. Obyek wisata yang membujur dari Utara (Pelabuhan Perikanan Nusantara) ke Selatan Pulau Nusakambangan dengan gelombang yang relatif cukup besar serta adanya pemandangan kapal-kapal tengker yang keluar masuk pelabuhan Tanjung Intan serta lalulalangnya nelayan tradisional mencari ikan dan mendarat pulang dari melaut. Obyek wisata Pantai Teluk Penyu disamping sebagai salah satu tujuan wisata juga sebagai tempat pemukiman para nelayan tradisional dengan berbagai aktifitasnya.

2. Geografi

Teluk penyu merupakan obyek wisata pantai Selatan, pantai Teluk Penyu terletak didalam kota Cilacap di wilayah Kelurahan Cilacap Kecamatan Cilacap Selatan Kabupaten Cilacap. Kondisi pantai ini landau dan jika dilihat dari atas berbentuk bulan sabit yang memiliki luas wilayah lebih kurang $14 \mathrm{Ha}$. Batas-batas wilayah pantai Teluk Penyu adalah sebagai berikut :
a. Sebelah Utara
: Kelurahan Tegal
b. Sebelah Selatan : Selat Kemulyan
Nusakambangan
c. Sebelah Timur : Samudra Hindia
d. Sebelah Barat : Desa Sidakaya

3. Identitas Pantai Teluk Penyu Cilacap
a. Nama
: Obyek Wisata Pantai
b. Alamat : Kelurahan Cilacap
Teluk Penyu Cilacap
Kecamatan Cilacap
Selatan Kabupaten
Cilacap
c. Luas : $14 \mathrm{Ha}$
d. Kelas : 1

\section{e. Pengelola : DISPARBUD}

4. Sarana dan fasilitas yang tersedia di Wisata Teluk Penyu

Adapun fasilitas yang dimiliki Wisata Teluk Penyu : Gerbang dan loket karcis tanda masuk, jalan aspal hot mik, halaman parker dengan paving blok, jalan setapak menggunakan paving blok, Mushola, toilet umum sekala nasional, MCK, panggung hiburan, panjat tebing, Gazebo bamboo, Gardu pandang dengan payung.

Tabel 3.1 :Daftar Kios

\begin{tabular}{llc}
\hline No. & \multicolumn{1}{c}{ Jenis } & Jumlah \\
\hline 1 & Kios penjual lkan asin & 40 \\
\hline 2 & Kios Cindera mata & 25 \\
\hline 3 & Kios makanan minuman & 20 \\
\hline 4 & Rumah makan lesehan ikan bakar & 10 \\
\hline
\end{tabular}

Tabel 3.2 : Data Kunjungan di Obyek Wisata Pantai Teluk Penyu Cilacap

\begin{tabular}{lllllllll}
\hline No. & $\begin{array}{l}\text { Obyek } \\
\text { wisata }\end{array}$ & \multicolumn{6}{c}{ Tahun } \\
\hline & \multicolumn{1}{c}{2007} & 2008 & 2009 & 2010 & 2011 & 2012 & 2013 \\
\hline 1. & Pantai teluk & 1067 & 1357 & 2575 & 3136 & 29657 & 2709 & 20037 \\
penyu & 26 & 84 & 57 & 41 & 5 & 96 & 1 \\
\hline \multicolumn{4}{r}{ Di tahun } & 2013 & orang yang & berkunjung
\end{tabular}
di obyek wisata Pantai Teluk Penyu Cilacap yaitu dua ratus ribu tiga ratus tujuh puluh satu jiwa.

5. Data pedagang ikan asin Jambal roti

Data pedagang yang diambil 10 sampel ikan asin Jambal roti di kawasan wisata Teluk Penyu Cilacap.

Tabel 3.3 :Data pedagang Ikan asin Jambal roti di kawasan wisata Teluk Penyu Cilacap tahun 2014

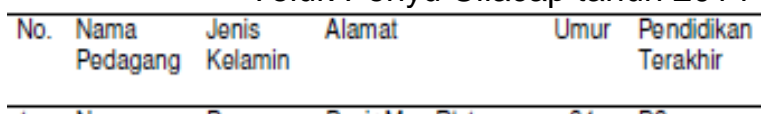

\begin{tabular}{llllll}
\hline 1 & Nu & P & $\begin{array}{l}\text { Pasir Mas Rt 1 } \\
\text { Rw7 }\end{array}$ & 34 & D3 \\
\hline 2 & $\mathrm{Ag}$ & $\mathrm{L}$ & $\begin{array}{l}\text { Pasir Mas Rt2 } \\
\text { Rw7 }\end{array}$ & 50 & SD \\
\hline 3 & Im & L & $\begin{array}{l}\text { Tegal Mulya Rt2 } \\
\text { Rw7 }\end{array}$ & 28 & SD \\
\hline
\end{tabular}

\begin{tabular}{|c|c|c|c|c|c|}
\hline & & & RW/ & & \\
\hline 4 & $\mathrm{Da}$ & $\mathrm{P}$ & Jl.Penyu Rt4 Rw14 & 60 & SD \\
\hline 5 & $\mathrm{Ta}$ & $\mathrm{P}$ & Jl.Cakalang No.3 & 46 & - \\
\hline 6 & $\mathrm{Da}$ & $P$ & J.Laut Rt5 Rw15 & 34 & SLTA \\
\hline 7 & $\mathrm{Dr}$ & $P$ & Pasir Mas & 33 & SMK \\
\hline 8 & $\mathrm{Ta}$ & $P$ & $\begin{array}{l}\text { JI.Cakalang Ri5 } \\
\text { Rw13 }\end{array}$ & 41 & $\mathrm{SD}$ \\
\hline 9 & $\mathrm{Ti}$ & $P$ & Jl.Penyu Rt8 Rw6 & 48 & SMP \\
\hline 10 & Su & $P$ & J.Cakalang & 50 & SD \\
\hline
\end{tabular}

Keterangan :

L : Laki-laki

$\mathrm{P}$ : Perempuan

\section{B. Gambaran Khusus}

Data khusus dari penelitian ini memberikan gambaran tentang kondisi fisik ikan asin Jambal roti, mengukur tingkat pengetahuan pedagang, mengukur besarnya 
kadar formalin pada ikan asin Jambal roti (Arius thalassinus) dan mengetahui ciri-ciri ikan asin jambal roti yang mengandung formalin dan tanpa formalin yang dijual di kawasan wisata Teluk Penyu Cilacap Tahun 2014.

1. Kondisi Fisik Ikan Asin Jambal Roti (Arius thalassinus) yang dijual di kawasan wisata Teluk Penyu Cilacap tahun 2014

Pengukuran kondisi fisik ikan asin Jambal roti (Arius thalassinus) yang dilakukan oleh peneliti dengan menggunakan lembar checklist, sebanyak 10 sampel dapat dilihat pada tabel 4.4 sebagai berikut :

Tabel 3.4 :Data hasil observasi kondisi fisik ikan asin Jambal roti yang dijual pedagang di kawasan Wisata Teluk Penyu Cilacap

\begin{tabular}{ccccc}
\hline No. & Pedagang & Nilai & Presentase $(\%)$ & Kalegori \\
\hline 1. & 1 & 5 & 100 & Baik \\
\hline 2. & 2 & 5 & 100 & Baik \\
\hline 3. & 3 & 5 & 100 & Baik \\
\hline 4. & 4 & 5 & 100 & Baik \\
\hline 5. & 5 & 4 & 80 & Baik \\
\hline 6. & 6 & 1 & 20 & Kurang \\
\hline 7. & 7 & 3 & 60 & Cukup \\
\hline 8. & 8 & 3 & 60 & Cukup \\
\hline 9. & 9 & 4 & 80 & Baik \\
\hline 10. & 10 & 5 & 100 & Baik \\
\hline & Hasil kondisi fisik sampel ikan asin
\end{tabular}

Jambal roti yang diukur secara organoleptik didapatkan hasil dengan kategori baik dengan presentase $70 \%$. Terdapat satu sampel dengan kategori kurang baik yaitu pedagang sampel 6 yang dinyatakan positif setelah dilakukan pemeriksaan di Laboratorium dan dilihat dari tekstur yang keras tidak mudah rusak, warna terang dan tidak berbau aroma khas ikan asin. Jadi terbukti sampel 6 positif mengandung bahan tambahan makanan berbahaya formalin dilihat dari kondisi fisik ikan asin sudah masuk dalam ciri-ciri ikan asin yang mengandung formalin.

2. Tingkat Pengetahuan Pedagang Ikan asin Jambal roti (Arius thalassinus) di kawasan Wisata Teluk Penyu Cilacap tahun 2014

Berdasarkan wawancara yang telah dilakukan peneliti kepadapedagang ikan asin Jambal roti tentang pengetahuan formalin sebagai bahan tambahan makanan yang dilarang didapatkan hasil sebagai berikut :
Tabel 3.5 :Hasil Observasi Tentang Tingkat Pengetahuan Pedagang

\begin{tabular}{lccll}
\hline No. & Penjual & Nilai & $\begin{array}{l}\text { Presentase } \\
(\%)\end{array}$ & Kategori \\
\hline 1 & 1 & 3 & 42,8 & Kurang \\
\hline 2 & 2 & 7 & 100 & Baik \\
\hline 3 & 3 & 3 & 42,8 & Kurang \\
\hline 4 & 4 & 7 & 100 & Baik \\
\hline 5 & 5 & 6 & 85,7 & Baik \\
\hline 6 & 6 & 4 & 57,1 & Cukup \\
\hline 7 & 7 & 1 & 14,28 & Kurang \\
\hline 8 & 8 & 1 & 14,28 & Kurang \\
\hline 9 & 9 & 5 & 71,42 & Cukup \\
\hline 10 & 10 & 7 & 100 & Baik \\
\hline
\end{tabular}

Pengetahuan pedagang masih rendah tentang formalin sebagai bahan tambahan makanan yang dilarang dari hasil wawancara menggunakan kuisioner didapatkan hasil penelitian pada 10 pedagang ikan asin $40 \%$ pedagang mempunyai kriteria baik $20 \%$ mempunyai kriteria cukup dan $40 \%$ memiliki kriteria kurang baik.

3. Kandungan Formalin pada Ikan asin Jambal roti (Arius thalassinus) yang dijual pedagang di kawasan Wisata Teluk Penyu Cilacap Tahun 2014

Tabel 3.6 : Hasil Laboratorium pemeriksaan kadar formalin pada ikan asin Jambal roti (Arius thalassinus)

\begin{tabular}{|c|c|c|c|c|}
\hline No. & Kode & Hasil & $\begin{array}{l}\text { Hasil } \\
\text { Pemeriksaan } \\
\text { Formalin }\end{array}$ & Standart" \\
\hline 1 & 1 & - & Negatif & \multirow{10}{*}{$\begin{array}{l}\text { Formalin } \\
\text { (Formaldehide) } \\
\text { termasuk bahan } \\
\text { yang dilarang } \\
\text { digunakan sebagai } \\
\text { Bahan Tambahan } \\
\text { Makanan. }\end{array}$} \\
\hline 2 & 2 & - & Negatif & \\
\hline 3 & 3 & - & Negatif & \\
\hline 4 & 4 & - & Negatif & \\
\hline 5 & 5 & - & Negatif & \\
\hline 6 & 6 & + & Positif & \\
\hline 7 & 7 & - & Negatif & \\
\hline 8 & 8 & - & Negatif & \\
\hline 9 & 9 & - & Negatif & \\
\hline 10 & 10 & - & Negatif & \\
\hline
\end{tabular}

Pemeriksaan kadar formalin pada ikan asin Jambal roti dilakukan di Laboratorium JKL dengan menggunakan Rapid Test Kit. Jumlah sampel ikan asin Jambal roti yang diperiksa sebanyak 10 sampel. Hasil pemeriksaan dari 10 sampel, 9 sampel negatif (tidak mengandung formalin) pada sampel nomer $1,2,3,4,5,7,8,9,10$ dan 1 sampel positif pada sampel 6 mengandung formalin $0,5 \mathrm{mg}$.

4. Ciri-ciri ikan asin Jambal roti (Arius thalassinus) yang berformalin dan tanpa formalin

Ciri khas ikan jambal roti yaitu aroma harum tekstur empuk, lemas, warna buram / merah / alami, dan digoreng 
renyah, lalat mau hinggap, cepat terkena jamur / belatung, bertahan \pm 1 bulan jika lebih dari itu akan ada perubahan warna pada ikan menjadi coklat kehitaman.

Ikan asin Jambal roti yang mengandung formalin dapat diketahui lewat ciri-ciri antara lain tidak rusak sampai lebih dari 1 bulan pada suhu 25 ${ }^{\circ} \mathrm{C}$, bersih cerah dan tidak berbau khas ikan asin. Tidak dihinggapi lalat di area berlalat (Astuti, 2010). Selain itu dagingnya kenyal,utuh, lebih putih dan bersih (Widyaningsih dan Murtini, 2006).

Hasil penelitian fisik terdapat ciri-ciri ikan asin yang mengandung formalin yaitu pada sampel 6 yang dilihat mempunyai tekstur yang keras tidak mudah rusak, warna terang dan tidak berbau aroma khas ikan asin dan setelah dilakukan pemeriksaan di Laboratorium dinyatakan positif. Jadi terbukti sampel 6 positif mengandung bahan tambahan makanan berbahaya.

\section{PEMBAHASAN}

\section{A. Gambaran Umum}

Obyek Wisata Pantai Teluk Penyu Cilacap adalah obyek wisatapantai Selatan atau Samudra Hindia terletak di wilayah Kelurahan Cilacap, Kecamatan Cilacap Selatan Kabupaten Cilacap, 1 km dari kantor kelurahan dan $2 \mathrm{~km}$ dari pusat pemerintahan Kabupaten Cilacap dapat ditempuh dengan kendaraan pribadi dan kendaraan umum angkutan wisata.

Teluk ini cukup memiliki pemandangan yang indah dengan luas $\pm 14 \mathrm{Ha}$. Area teluk penyu yang biasa dikunjungi oleh para pengunjung (utamanya penduduk dan wisatawan lokal) biasanya mulai dari pelabuhan perikanan Samudra dari hingga bibir pantai. Di sepanjang pantai yang tertata rapi terutama dari arah pintu masuk area wisata Pantai Teluk Penyu banyak berdiri kios-kios /warung yang menjajakan ikan asin kering ada 40 penjual ikan asin yang dijual disepanjang koridor jalan masuk lokasi wisata ini. Kawasan wisata ini ramai dikunjungi pada waktu pagi dan sore hari oleh para penduduk kota Cilacap sedangkan pada siang hari lebih banyak dikunjungi oleh para wisatawan lokal utamanya pada masamasa libur sekolah atau pada hari-hari besar.

\section{B. Gambaran Khusus}

1. Kondisi Fisik Ikan asin Jambal roti (Arius thalassinus) yang dijual di kawasan wisata Teluk Penyu Cilacap tahun 2014
Ikan jambal roti adalah produk ikan asin yang berasal dari ikan Manyung (Arius thalassinus) Burhannudin,(1987).

Berdasarkan pengamatan penelitian secara langsung dan dengan menggunakan lembar checklist adalah

a. Kondisi fisik ikan asin Jambal roti dari 10 sampel pedagang yang memiliki tekstur lemas dengan presentase 100 $\%$.

b. Kondisi fisik ikan asin Jambal roti dari 10 sampel pedagang yang memiliki tekstur empuk dengan presentase 90 $\%$.

c. Kondisi fisik ikan asin Jambal roti dari 10 sampel pedagang yang memiliki aroma khas dengan presentase $90 \%$.

d. Kondisi fisik ikan asin Jambal roti dari 10 sampel pedagang yang memiliki warna buram alami dengan presentase $50 \%$.

e. Kondisi fisik ikan asin Jambal roti dari 10 sampel pedagang ikan asin yang dihinggapi oleh lalat dengan presentase $70 \%$.

Sebanyak 10 sampel menunjukan hasil kondisi fisik sampel yang diukur secara organoleptik didapatkan hasil dengan kategori baik dengan presentase $70 \%$.

Untuk sampel 7 dan 8 yang dinilai dalam kategori cukup baik dikarenakan pada saat peneliti melakukan observasi kondisi fisik ikan berwarna putih terang tetapi pada saat pemeriksaan di Laboratorium tidak positif mengandung formalin, dimungkinkan karena pada proses penggaraman, garam yang digunakan $\mathrm{Mg}$ (magnesium) dan $\mathrm{Ca}$ (calsium) yang akan menghambat proses penetrasi garam kedalam daging ikan, akibatnya daging ikan berwarna putih cerah.

Kelemahan dari penelitian ini adalah penguji organoleptik hanya dilakukan oleh dua orang. Hal tersebut dapat menyebabkan hasil yang kurang representative. Uji organoleptik merupakan pengujian yang dilakukan menggunakan indra peraba, pembau, pengeliatan, perasa, dan pendengar. Uji ini bersifat subyektif dalam arti penilaian yang diberikan oleh setiap orang dapat berbeda-beda. Pengujian organoleptik hendaknya dilakukan lebih dari 2 orang, sehingga didapatkan hasil yang lebih akurat.

2. Tingkat Pengetahuan Pedagang Ikan asin Jambal roti (Arius thalassinus) di kawasan Wisata Teluk Penyu Cilacap tahun 2014 
Berdasarkan pengamatan secara langsung dan dengan menggunakan lembar Kuisioner yang dilakukan terhadap pedagang ikan asin Jambal roti adalah

a. Tingkat pengetahuan pedagang tentang bahan pengawet yang bernama formalin dengan presentase $60 \%$.

b. Tingkat pengetahuan pedagang tentang larangan penggunaan formalin sebagai bahan tambahan makanan dengan presentase $40 \%$.

c. Tingkat pengetahuan pedagang tentang ciri-ciri ikan asin berformalin dengan presentase $70 \%$.

d. Tingkat pengetahuan pedagang tentang bahayanya formalin bagi kesehatan dengan presentase $60 \%$.

e. Tingkat pengetahuan pedagang tentang untuk apa sebenarnyaformalin itu bisa digunakan dengan presentase $60 \%$.

f. Tingkat pengetahuan pedagang tentang pernah adanya sosialisasi dari dinas dengan presentase $100 \%$.

g. Pedagang yang telah mengikuti sosialisasi/penyuluhan yang dilakukan oleh dinas dengan presentase $40 \%$.

Hasil observasi penelitian pada 10 pedagang ikan asin tingkat pengetahuan pedagang masih rendah tentang bahan tambahan makanan yang dilarang yaitu formalin dari hasil wawancara didapatkan hasil penelitian pada 10 pedagang ikan asin $40 \%$ pedagang mempunyai kriteria baik, $20 \%$ mempunyai kriteria cukup dan $40 \%$ memiliki kriteria kurang baik.

Maka peneliti perlu memberi masukan tentang bahaya formalin sebagai bahan tambahan makanan sehingga dikemudian hari tahu akan bahaya formalin sebagai bahan tambahan makanan. Akibatnya jika digunakan pada makanan dan dikonsumsi oleh manusia akan menyebabkan beberapa gejala diantaranya tenggorokan terasa panas bisa menyebabkan kanker yang berbahaya.

Meningkatnya pengetahuan pedagang dapat menghindari dampak yang tidak diinginkan bagi masyarakat yang disebabkan karena penggunaan bahan tambahan terlarang pada makanan. Para penjual ikan asin di wilayah Teluk Penyu Cilacap sebaiknya diberi pengarahan oleh pihak dinas kesehatan secara rutin tentang penggunaan bahan tambahan makanan yang (formalin) yang dilarang oleh pemerintah, sehingga penjual ikan asin di kawasan wisata Teluk Penyu Cilacap dapat mengerti mengikuti informasi mengenai makanan sehat dan mengerti tentang penggunaan bahan tambah makanan yang dilarang oleh pemerintah.

3. Hasil Pemeriksaan Formalin pada Ikan asin Jambal roti (Arius thalassinus) yang dijual di kawasan Wisata Teluk Penyu Cilacap Tahun 2014

Data yang diperoleh dari kantor Dinas Pariwisata Dan Kebudayaan Kabupaten Cilacap menyebutkan sarana dan fasilitas yang tersedia antaranya kios makanan yang menjajakan ikan asin kering ada 40 penjual ikan asin yang dijual disepanjang koridor jalan masuk lokasi wisata ini. Sampel ikan asin yang diambil yaitu ikan asin Jambal roti yang dijual dalam kemasan.

Dari hasil survey pedagang ikan asin Jambal roti 10 pedagang yang diambil sampel diantaranya 9 pedagang ikan asin memproduksi ikan sendiri dan yang 1 pedagang mengambil dari produsen KUB Mandiri yang berada di Jl.Bakung Cilacap dengan nama pemilik lbu Sugina. Pengambilan sampel ikan asin Jambal roti pada penelitian kadar formalin dilaksanakan pada hari kamis tanggal 19 Juni 2014.

Tabel 4.1 Waktu pengambilan sampel

\begin{tabular}{|c|c|c|}
\hline №. & Nama Pedagangyg diambil sampel & Waktu \\
\hline 1 & Podagang 1 sampel 1 & 10.03 \\
\hline 2 & Pedagang 2 sampel 2 & 10.15 \\
\hline 3 & Pedagang 3 sampel 3 & 10.23 \\
\hline 4 & Pedagang 4 sampel 4 & 10.30 \\
\hline 5 & Pedagang 5 sampel 5 & 10.35 \\
\hline 6 & Pedagang 6 sampel 6 & 10.47 \\
\hline 7 & Pedagang 7 sampel 7 & 10.55 \\
\hline 8 & Pedagang 8 sampel 8 & 11.00 \\
\hline 9 & Pedagang 9 sampe 19 & 11.07 \\
\hline 10 & Pedagang 10 sampel 10 & 11.20 \\
\hline
\end{tabular}

Pemeriksaan ikan asin Jambal roti pada penelitian ini menggunakan metode Rapid test kit. Prinsip kerjanya adalah dengan mengambil larutan sampel kemudian ditambahkan 10 tetes reagent formaldehyde lalu celupkan test strip dan bandingkan dengan skala.

Berdasarkan pemeriksaan yang dilakukan di Laboratorium 10 sampel yang diperiksa dari masing masing pedagang ikan asin menunjukan 1 sampel dinyatakan positif dan 9 sampel dinyatakan negatif (tidak mengandung formalin). Pemeriksaan dilakukan di Laboratorium Poltekkes Kemenkes Semarang yang dilaksanakan pada hari Kamis tanggal 19 Juni 2014 dengan 10 sampel. Dapat diketahui bahwa dari 10 sampel 1 dinyatakan positif mengandung formalin $0,5 \mathrm{mg}$ pada sampel 6 dan pada 
sampel

$1,2,3,4,5,7,8,9,10$ dinyatakan negatif.

Sampel 6 yang dinyatakan positif (mengandung formalin) tidak layak dikonsumsi menurut Peraturan Menteri Kesehatan Republik Indonesia No.033/Menkes/Per/IX/2012

mendefinisikan bahan tambahan yang dilarang dalam makanan. Saparinto,dkk, (2006, h.62) menjelaskan bahwa formalin tidak boleh digunakan sebagai bahan pengawet untuk pangan. Akibatnya jika digunakan pada pangan dan dikonsumsi oleh manusia akan menyebabkan beberapa gejala diantaranya adalah tenggorokan terasa panas dan kanker yang pada akhirnya akan mempengaruhi organ tubuh lainya, serta gejala lainya.

Pengaruh Formalin terhadap kesehatan jika terhirup (Inhalasi) rasa terbakar pada hidung dan tenggorokan, sukar bernafas, nafas pendek, sakit kepala, kanker paru-paru. Jika terkena kulit (Perkutan) kemerahan, gatal, kulit terbakar. Jika terkena mata kemeraham, gatal, mata berair, kerusakan mata, pandangan kabur, kebutaan. Jika tertelan (Ingesti) mual, muntah, perut perih, diare, sakit kepala, pusing, gangguan jantung, kerusakan hati, kerusakan saraf, kulit membiru, hilangnya pandangan, kejang, koma, dan kematian (Saparinto,dkk,h.62)

Sebaiknya dilakukan pemeriksaan oleh petugas BPOM dan petugas Puskesmas pada pedagang ikan asin terutama pada produsen ikan asin karena sampel 6 yang dinyatakan positif formalin pedagang yang mengambil dari produsen tidak memproduksi sendiri. Maka sebaiknya diberi pengawasan oleh petugas secara rutin karena produsen memproduksi ikan asin yang banyak untuk diedarkan kepada pedagang dan diberi pengetahuan sosialisasi atau penyuluhan oleh Dinas supaya para pedagang ikan asin tidak menggunakan bahan tambahan makanan (formalin) yang dilarang oleh pemerintah.

\section{SIMPULAN DAN SARAN}

\section{A. Simpulan}

Berdasarkan penelitian tentang kadar formalin pada ikan asin Jambal roti (Arius thalassinus) di kawasan Wisata Teluk Penyu Cilacap Tahun 2014, maka dapat disimpulkan sebagai berikut :

1. Kondisi fisik sampel ikan asin Jambal roti (Arius thalassinus) sebanyak 10 sampel didapatkan hasil dengan kategori baik presentase $70 \%$. Untuk sampel 7 dan 8 yang dinilai dalam kategori cukup baik dikarenakan pada saat peneliti melakukan observasi kondisi fisik ikan berwarna putih terang tetapi pada saat pemeriksaan di Laboratorium tidak positif mengandung formalin, dimungkinkan karena garam yang digunakan pada saat pembuatan ikan asin menggunakan garam yang mengandung $\mathrm{Mg}$ (magnesium) dan $\mathrm{Ca}$ (calsium) yang akan menghambat proses penetrasi garam kedalam daging ikan akibatnya daging ikan berwarna putih.

2. Tingkat pengetahuan pedagang ikan asin Jambal roti masih rendah tentang BTP yang dilarang (formalin) berdasarkan wawancara yang telah dilakukan peneliti kepada pedagang ikan asin, terdapat $60 \%$ pedagang yang belum memiliki pengetahuan yang baik maka peneliti perlu memberi masukan tentang bahaya formalin sebagai BTP sehingga dikemudian hari pedagang tersebut mengetahui tentang bahaya formalin sebagai BTP yang dilarang.

3. Sampel 6 dinyatakan positif mengandung formalin $0,5 \mathrm{mg}$ maka dinyatakan tidak aman untuk dikonsumsi oleh masyarakat dan tidak layak dikonsumsi menurut Peraturan Menteri Kesehatan Republik Indonesia No.033/Menkes/Per/IX/2012 mendefinisikan bahan tambahan yang dilarang dalam makanan.

4. Ciri-ciri ikan asin Jambal roti (Arius thalassinus) yang berformalin sampel 6 yang mempunyai tekstur yang keras tidak mudah rusak, warna terang dan tidak berbau aroma khas ikan asin dan setelah dilakukan pemeriksaan di Laboratorium dinyatakan positif. Jadi terbukti sampel 6 positif mengandung BTP berbahaya formalin dilihat dari kondisi fisik ikan asin sudah masuk dalam ciri-ciri ikan asin yang mengandung formalin.

\section{B. Saran}

1. Bagi Dinas Kesehatan

a. Kerja sama dengan Dinas Kesehatan Kabupaten Cilacap untuk meningkatkan pengawasan dan pemeriksaan mutu makanan.

b. Pemerintah memberikan penyuluhan akan bahaya penggunaan formalin $\rightarrow$ nelayan, produsen, konsumen.

c. Mengefektifkan SISPOM (Sistem Pengawasan Obat dan Makanan) sebagai tugas pokok fungsi dari BP POM.

d. Diperlukan adanya intervensi langsung pemerintah dalam bentuk pengawasan langsung, agar mengetahui kondisi sebenarnya.

2. Bagi Masyarakat 
a. Masyarakat lebih berhati-hati dalam memilih bahan makanan terutama ikan asin dan perlu mengetahui tentang ciriciri fisik ikan asin yang berformalin dan ikan asin yang tidak mengandung formalin.

b. Harus bisa mengenali ciri-ciri produk yang mengandung formalin, dan tidak terpengaruh dengan penampilan luar produk.

3. Bagi pedagang

a. Sebaiknya pedagang selalu menjaga kebersihan dan tetap menjaga kualitas ikan asin yang dijual dan tidak menambahkan bahan formalin sebagai bahan pengawet dalam ikan asin.

b. Kesadaran produsen dari industri perikanan harus ditingkatkan untuk mencapai keamanan produk

4. Bagi Peneliti lain

Peneliti lain dapat melanjutkan penelitian tentang kadar formalin pada jenis makanan atau minuman jenis lain.

\section{DAFTAR PUSTAKA}

Afrianto,Edi dan Evi Liviawaty, 1993, Pengawetan dan Pengolahan Ikan, Jakarta : Kanisius.

Aziz alimul Hidayat,2007, Metode Penelitian Kebidanan dan Teknik Analisis Data, Jakarta : Salemba Medika.

Burhanudin,Martosewojo dan M.Hoetomo,1987,Sumber Daya Ikan Manyung di Indonesia,Jakarta:LON-LIPI.

Chandra, Budiman, 2006, Pengantar Kesehatan Lingkungan, JKT:EGC. Departemen Kesehatan RI Berdasarkan Peraturan Menteri Kesehatan

No.033/Menkes/Per/IX/2012.

Djamaluddin Ramlan dan Maisye Marlyn Kuhu, 2013, Penulisan Penelitian Diskriptif, Purwokerto : UPT Percetakan dan Penerbitan Unsoed.

Erwan,M, 1992, Pengaruh Konsentrasi Gula dan Garam Terhadap Mutu Ikan Jambal Roti, Skripsi, Fakultas Perikanan, IPB, Bogor.

F.G. Winarno, 1994, Bahan Tambahan dan Kontaminan, JaKarta : Pustaka Sinar Harapan.

Handayani,2006,Bahaya Kandungan Formalin pada Makanan.
Http : // berita.liputan6.com/read/242317/dagingberformalin-disita-petugas 19 Sep 2011. Diakses tanggal 2 Februari 2014

Http : // www.malang.post.com/metroraya/80591waspada-ikan-berformalin (Minggu 19 Januari 2014 12:22) Diakses tanggal 15 Februari 2014

Http : // www.ahliwasir.com/news/1997/C iri-ciri4-Zat-Berbahaya-pada- Makanan. Astuti LDP,2010,Ciri-ciri 4 Zat Berbahaya pada Makanan. Diakses tanggal 22 Februari 2014

Hustyani, Rini dan Siti Nuryanti, 2006, Kasus Racun Formalin Http : // www.republika.co.id Diakses tanggal 8 Februari 2014

Mahdi, C dan Mubarrak, Shofi A,2008,"'Uji kandungan Formalin, Borak dan Pewarna Rhodamin pada Produk perikanan dengan metode spot test",Berkala IImiah Perikanan Vol.3, Universitas Brawijaya

Rachmawati,evi,2006,Bahaya Dibalik Gurihnya Ikan Asin. Http : // www.depkes.go.id Diakses tanggal 2 Januari 2014

Rahayu WP, Ma'oen S, Suliantari, Fardies S, 1992, Teknologi Fermentasi Produk Perikanan, Bogor: Debdibud, Dirjen, Dikti, PAU Pangan dan Gizi, IPB.

Tri Cahyono, 2009, Pedoman Penulisan KTI, Purwokerto : Kemenkes RI Depkes Semarang JKL.

Widyaningsih DT dan SM Erni,2006,Formalin,Surabaya : Penerbit Trubus Agrisarana.

Wisnu cahyadi,2006,Analisis dan Aspek Kesehatan Bahan Tambahan Pangan, Jakarta: Bumi Aksara. 